\title{
Management of Subterranean Clover in Pine Forested
}

Range

MARK K. JOHNSON, LEE G. DAVIS, KENNETH F. RIBBECK, JEFFREY H. RENDER, AND HENRY A. PEARSON

Abstract

Subterranean clover (Trifolium subterraneum) is a cool-season forage legume that can be grown in the southeastern United States. A vailable varieties grow best on well-drained sites and tolerate acid soil conditions producing adequate forage without addition of lime if soil $\mathrm{pH}$ is $\mathbf{4 . 8}$ or higher. However, at least during the first few years, annual applications of at least $50 \mathrm{~kg} / \mathrm{ha}$ of $\mathrm{P}_{2} \mathrm{O}_{5}$ and $\mathrm{K}_{2} \mathrm{O}$ are needed to maintain good production. In addition, summer growth of competing vegetation must be removed annually in late August or early September by heavy livetock grazing, use of herbicide, or close mowing. Unlike other clovers, subterranean will reseed even if heavily grazed during the flowering stage. Initial establishment under pine timber in the Southeast can be achieved by removal of hardwoods, prescribed burning, and broadcasting freshly inoculated seed on top of the soil in late October or early November when the soil surface is wet. Production of adequate forage before mid-winter remains a problem, especially if unregulated use by deer is heavy.

The 49 million ha of pine or mixed pine-hardwood forests in the southern United States (Shiflet 1980), represents a large land resource available for animal production. However, animal production is limited during fall and winter by nutritional deficiencies of native plants (Lay 1957, Blair et al. 1977).

Supplemental feeding or food plots to improve wildlife habitat has not been widely accepted by professional wildlife managers, but might become a valuable tool if the demand for game resources increases substantially (Ozoga and Verme 1982). The major deterent to planting large amounts of land for wildlife is the high annual cost for cultivation, seed, and fertilization. In some forests the lack of openings is also a limiting factor. Because there are few natural openings in managed pine forests, cattle must be supplemented with bagged feed or moved to improved pasture during winter (Davis 1983). Cows on forested range need supplemental feed in early winter to assure successful winter calving and spring breeding. Establishment of clearings for wildlife food plots or winter pastures is often not economical.

Here, we report the results of agroforestry research on establishment and production of subterranean clover under stands of pine timber thinned for sawlog production. We also provide management recommendations as to establishment, fertilization and maintenance under pine timber.

\section{Methods}

\section{Plot Establishment}

During summer 1981, we established study plots at 3 locations in Louisiana. At Lee Memorial Forest, near Bogalusa, La., 24 plots ( 0.1 ha each) in a natural stand of 30 to 35 year old loblollyshortleaf (Pinus taeda pine and P. echinata) were thinned and all hardwoods removed. Pine timber was crown-thinned to goals of 0 , 9,18 and $28 \mathrm{~m}^{2} /$ ha $\left(\simeq 0,40,80,120 \mathrm{ft}^{2} /\right.$ acre $)$ of basal area. Residual slash was piled and the plots prescribed burned. Another 24 plots

\footnotetext{
Authors are associate professor and graduate research assistants, School of Forestry, Wildlife, and Fisheries, Louisiana Agricultural Experiment Station, Louisiana State University Agricultural Center, Baton Rouge 70803; and chief range scientist. Southern Forest Experiment Station, 2500 Shreveport Hwy., Pineville, La. 71360.

This research was conducted under McIntire-Stennis Project LA 2154 from the Louisiana Agricultural Experiment Station, LSU Agricultural Center, and under cooperative study FS-SO-1701-3.25 between LSU Agricultural Center and the Southern Forest Experiment Station. We thank F. Peterson, R. Delee, D. Reed, D. Rollins, $K$. Dancak, and $B$. Delany for assisting in various aspects of our field work.

Manuscript accepted 16 December 1985.
}

were established in the same manner at Idlewild Research Station, near Clinton, Louisiana. The natural pine timber was about the same age and species composition. At each of these 2 study areas 6 plots were established for each of the 4 thinnings goals for a total of 48 plots.

The third study area was located on the USDA Forest Service Palustris Experimental Forest near Glenmora, La. Study plots consisted of 20- to 25-year-old planted stands of slash ( $P$. elliotti) and longleaf ( $P$. palustris) pine. For each of the 2 pine species, 4 plots were established for each of the 4 thinning goals for a total of 32 plots. Because of initial injection of hardwoods, with herbicide and a 20-year history of prescribed burning on a 3-year rotation plus cattle grazing, hardwoods were rare on these plots. Following timber thinning, plots were prescribed burned in early September. All plots were fenced to eliminate use by cattle.

Plots on the Lee Memorial Forest study area were McKamie very fine and Ruston fine sandy loam soils; plots on the Palustris Experimental Forest were Malbis and Ruston fine sandy loams. Plots on Idlewild Research Station were on Providence silt loam. Soils were analyzed by the Soil Testing Laboratory, Louisiana Agricultural Experiment Station, using standard procedures (AOAC 1970). At all 3 locations soil $\mathrm{pH}$ ranged from 4.8 to 5.5 ; available phosphorus ( $P$ ) for all plots was very low $(5 \mathrm{ppm})$ and exchangable potassium (K) was low (40-60 $\mathrm{ppm}$ ) with respect to levels associated with excellent production of forage crops (Peevy 1972).

\section{Fertilization Tests}

General fertilization recommendations for growing clover on these soils is liming to raise $\mathrm{pH}$ above 6 and annual application of $108 \mathrm{~kg} / \mathrm{ha}$ of $\mathrm{P}_{2} \mathrm{O}_{5}$ and $67 \mathrm{~kg} / \mathrm{ha}$ of $\mathrm{K}_{2} \mathrm{O}(0-90-60 \mathrm{lb} / \mathrm{acre}$ ) (Peevy 1972). We were not certain as to whether this recommendation was optimum for subclover grown under timber without application of lime.

At Lee Forest and Idlewild, 3 plots for each thinning goal received $108 \mathrm{~kg} /$ ha each of $\mathrm{P}_{2} \mathrm{O}_{5}$ and $\mathrm{K}_{2} \mathrm{O}$ while the other 3 plots received half these amounts $(54 \mathrm{~kg} / \mathrm{ha})$. Half of the plots at the Palustris area received $54 \mathrm{~kg} /$ ha of each nutrient and half received none (Fig. 1).

In 1982 October, none of the plots previously fertilized at the lowest rates were fertilized. All other plots received $54 \mathrm{~kg} / \mathrm{ha}$ each of $\mathrm{P}_{2} \mathrm{O}_{5}$ and $\mathrm{K}_{2} \mathrm{O}$.

In September 1983, all plots previously fertilized both years were again fertilized with $54 \mathrm{~kg} /$ ha of each nutrient $(P, K)$, while the other plots received only $54 \mathrm{~kg} / \mathrm{ha}$ of $\mathrm{P}_{2} \mathrm{O}_{5}$.

Fertilization strategies were varied each year because clover production the first year did not differ significantly $(P>0.10)$ among any of the 3 original rates. Our purpose was to identify an optimum rate of fertilizer for a formulation such as 0-24-24, 0-20$20,0-20-0$, or $0-46-0$; that is usually available in bags. Our rationale was that many wildlife and livestock managers using forest range would have difficulty in obtaining equipment for hauling and spreading custom bulk mixed fertilizer, and large fertilizer trucks used for spreading bulk fertilizer usually can not be used in forests.

\section{Seeding Subterranean Clover}

During the last week of August 1981 at each study area, seed produced in Oregon from the Nangeela cultivar of subterranean clover was inoculated with the WR strain of Rhizobium trifolii selected for use with subterranean clover and broadcast seeded on top of the soil at $11 \mathrm{~kg} / \mathrm{ha}$ (Knight et al. 1976). Sugar and water 
Lee Forest
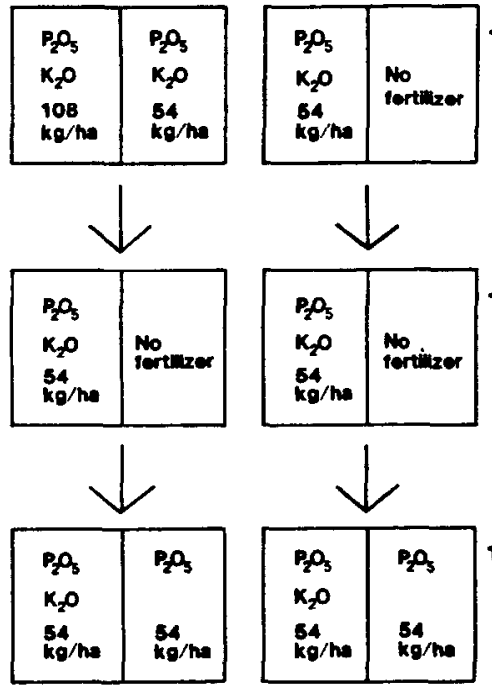

1982

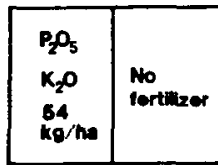

1981
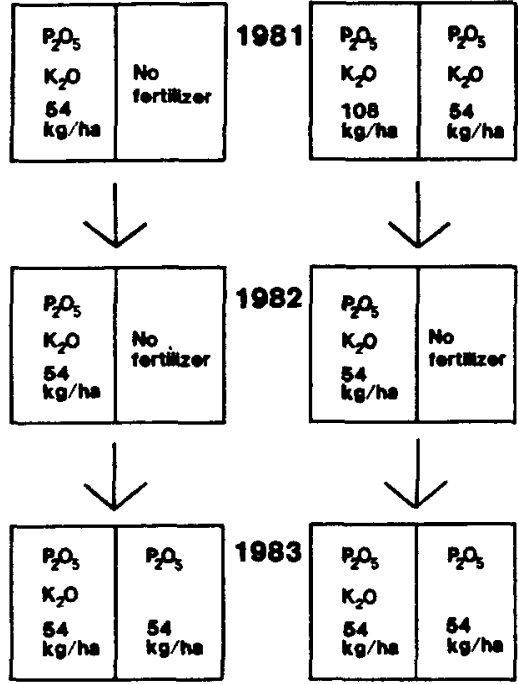

Fig. 1. Scheme for fertilization tests for subterranean clover production under southern pines. Each nutrient was applied at the indicated rate.

were used to make an inoculum sticker (Gardner et al. 1979). All seeding for our experiments was performed with hand-held broadcast seeders. We found that large amounts of freshly inoculated seed usually clogged large implement seeders.

Following the initial year, plots were mown and burned in late August or early September to reduce competition and shading from standing understory vegetation. Subterranean clover seed, produced the previous spring, germinated following the September and October rains.

\section{Clover Sampling}

During mid-May 1982 and each May thereafter, 3 clover samples $(20$ by $20 \mathrm{~cm})$ were clipped from each study plot at each location. Samples were dried at $60^{\circ} \mathrm{C}$ for 48 hours in a convection oven, and weighed to the nearest $0.1 \mathrm{~g}$.

\section{Timber Canopy Measurements}

Understory production is more associated with tree canopy than with basal area (McLaughlin 1978). Average percent canopy cover was estimated for each clipped plot of clover with a spherical densiometer by following the 17-point technique described by Strickler (1959).

\section{Statistical Analyses}

Student's $t$ tests for paired treatments were used to compare clover production between fertilization schemes and regeneration treatments (Snedecor and Cochran 1973). Pine timber basal area thinning goals were used to pair grand mean clover yields among plots having the same thinning goals. Stepwise regression was used to determine whether clover production $(Y)$ was significantly influenced by pine canopy cover (X). Because understory yield is usually lower under heavier timber densities than lower timber densities (Wolters 1981), we used a l-tailed test to determine if the slope of the relationship ( $Y=a+B X)$ was significantly different from zero. Analysis of covariance was used to determine if the relationship varied significantly among the 3 study areas or fertilizer treatments (Steel and Torrie 1980). Statistical significance was accepted at the 0.05 level.

\section{Results and Discussion}

\section{Clover Establishment and Yields}

Although clover established well in 1981 on all study plots at Lee Memorial Forest and Idlewild Research Station, only 5 of the plots at the Palustris Experimental Forest produced nodulated plants. Toms (1958), Morley (1961), Date (1970), and Jones et al. (1971) emphasized that survival of Rhizobium bacteria is highly dependent on incidence of rain after sowing, especially if seed is broadcast and left on the soil surface. Rhizobium suffers more than $99 \%$ mortality if there is no rain for 7 days following seeding. Based on records kept daily at each study site, there was only $4.1 \mathrm{~cm}$ of precipitation after seeding on Palustris plots and precipitation during the previous month was only about $25 \%(2.6 \mathrm{~cm})$ of average $(9.8 \mathrm{~cm})$ while Idlewild and Lee Forest received $11.9 \mathrm{~cm}$ and 18.6 $\mathrm{cm}$ of precipitation, respectively. We suggest that without harrowing, seeding should be deferred until a wet period in late October or early November when additional rain and/or cool weather is expected.

There are a variety of commercial inoculum stickers available and these may increase success of establishment during dry peri-

Table 1. Mean ( \pm SE) oven dry yields ( $\mathrm{kg} / \mathrm{ha}$ ) of subterranean clover on cleared and pine forested plots (0.01 ha) at 3 locations in Louisiana. Plots were clipped during mid-May each year. There were 3 clipped plots for each of 3 study plots at each location except Palustris where there was only 1 study plot clipped for each treatment. Each mean is a grand average calculated among the average yields from each plot.

\begin{tabular}{|c|c|c|c|c|c|c|}
\hline \multirow[b]{2}{*}{$\begin{array}{l}\text { Pine Basal Area } \\
\text { Thinning Goal } \mathrm{m}^{2} / \text { ha }\end{array}$} & \multicolumn{6}{|c|}{ Year of May Sample } \\
\hline & \multicolumn{2}{|c|}{1982} & 1983 & Low & \multicolumn{2}{|c|}{1984} \\
\hline $\begin{array}{c}\text { Lee Forest } \\
0 \\
9 \\
18 \\
28\end{array}$ & $\begin{array}{l}1855 \pm 113 \\
1204 \pm 218 \\
1176 \pm 69 \\
1572 \pm 435\end{array}$ & $\begin{array}{l}1366 \pm 6 \\
1222 \pm 137 \\
1807 \pm 277 \\
1120 \pm 290\end{array}$ & $\begin{array}{l}2157 \pm 275 \\
1475 \pm 207 \\
1611 \pm 11 \\
1417 \pm 256\end{array}$ & $\begin{array}{l}1597 \pm 99 \\
1039 \pm 10 \\
1019 \pm 21 \\
1172 \pm 101\end{array}$ & $\begin{array}{r}1667 \pm 694 \\
864 \pm 134 \\
522 \pm 284 \\
764 \pm 540\end{array}$ & $\begin{array}{l}828 \pm 308 \\
428 \pm 255 \\
361 \pm 184 \\
639 \pm 321\end{array}$ \\
\hline $\begin{array}{c}\text { Idlewild } \\
0 \\
9 \\
18 \\
28\end{array}$ & $\begin{array}{l}3786 \pm 299 \\
2443 \pm 230 \\
2514 \pm 133 \\
2315 \pm 534\end{array}$ & $\begin{array}{l}3659 \pm 130 \\
2732 \pm 346 \\
2798 \pm 144 \\
2817 \pm 398\end{array}$ & $\begin{array}{l}3298 \pm 77 \\
2213 \pm 230 \\
2641 \pm 188 \\
1736 \pm 327\end{array}$ & $\begin{array}{l}2487 \pm 577 \\
1842 \pm 313 \\
1022 \pm 167 \\
1128 \pm 93\end{array}$ & $\begin{array}{l}2147 \pm 1105 \\
1607 \pm 343 \\
1664 \pm 247 \\
1125 \pm 455\end{array}$ & 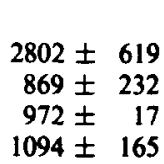 \\
\hline $\begin{array}{c}\text { Palustris } \\
9 \\
18\end{array}$ & $\begin{array}{l}2979 \pm 339 \\
3373 \pm 140\end{array}$ & $\begin{array}{l}2719 \pm 375 \\
3002 \pm 213\end{array}$ & $\begin{array}{l}3980 \pm 164 \\
4360 \pm 187\end{array}$ & $\begin{array}{l}1300 \pm 321 \\
2125 \pm 791\end{array}$ & $\begin{array}{l}3424 \pm 837 \\
1693 \pm 238\end{array}$ & $\begin{array}{l}2458 \pm 1193 \\
1020 \pm 260\end{array}$ \\
\hline
\end{tabular}

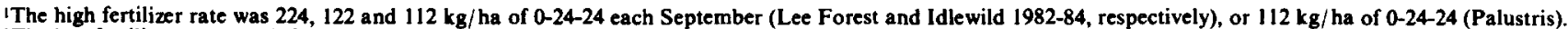

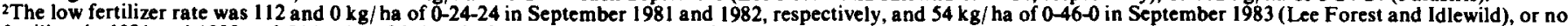
fertilizer in 1981 and 1982 and $54 \mathrm{~kg} / \mathrm{ha}$ of $0-46-0$ in September 1983 (Palustris). 
ods. However, we were not able to test these products because each time we tried to, rainfall was excellent. Regardless, there is probably no good substitute for seeding under optimum conditions, especially when seed is being broadcast and not covered.

For the establishment year, yields ranged from about 1,200 to $3,800 \mathrm{~kg} / \mathrm{ha}$. Plots at Lee Memorial Forest produced the least clover all 3 years regardless of fertilizer treatment (Table 1). Yields were similar for the first 2 years but yields for the third year were generally much lower. We believe that this was partly a result of having an unusually cold winter during 1983-84.

Producing improved forages under pine timber is not a new idea. Halls and Suman (1954) produced white clover (T. repens) under pole and sawtimber longleaf pines in southern Georgia. Although they were successful, certain management problems arose, especially after the first year. They attributed declining production to a build up of pine needles under the trees, especially where timber stocking was greatest. Visual inspection of our plots suggested that pine needle build-up was probably a major contributor to the decline in clover production among years.

\section{Fertilization Tests}

During the first year, clover yields did not differ significantly among plots that were unfertilized, or those that received either 224 or $448 \mathrm{~kg} / \mathrm{ha}$ of $0-24-24$. However, by the second May fertilized plots produced significantly more clover on all 3 study areas. Mean increases due to P plus K were 40,66 , and $155 \%$ for Lee Forest, Idlewild and Palustris study sites, respectively. This pattern was similar for the third year when both fertilization strategies included $54 \mathrm{~kg} /$ ha of $\mathrm{P}_{2} \mathrm{O}_{5}$, but only half of the plots received any $\mathrm{K}_{2} \mathrm{O}(54$ $\mathrm{kg} / \mathrm{ha}$ ). On the basis of these results, we suggest that subterranean clover should be fertilized annually with $224 \mathrm{~kg}$ / ha of $0-24-24$, or equivalent. This rate includes phosphorus at about half the level normally recommended for soils with higher $\mathrm{pH}$. Higher yields might be obtained in forested pastures if lime is applied and more phosphorus might be needed to maximize growth. More information is needed regarding the effects of livestock grazing and fertilization strategies before optimum recommendations for managing subterranean clover under pine timber can be identified.

\section{Timber Canopy vs Subterranean Clover Yield}

Subterranean clover yields were highly associated with canopy cover $\left(r^{2}=0.80\right)$ and the relationship varied significantly among study sites (Fig. 2). However, the association was less significant

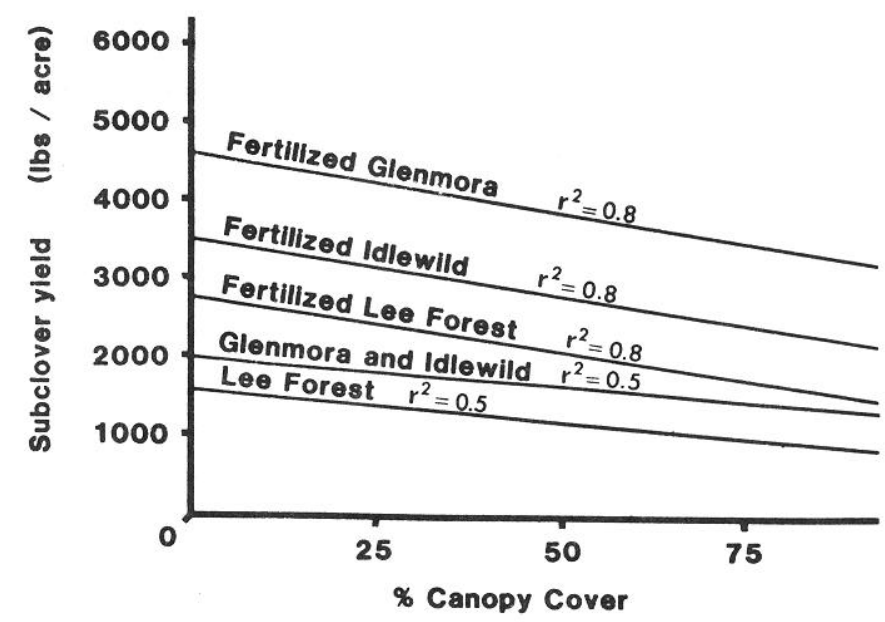

Fig. 2. Relationships between fertilization, pine canopy density, site and subclover yield.

for unfertilized plots $\left(r^{2}=0.50\right)$. In general, yields were about $25-30 \%$ less in forested plots than cleared plots. This suggests that subterranean clover pastures can be produced on appropriate, well-drained sites under managed pine (Fig. 3). Pine timber does not need to be thinned more heavily than would be normal for sawlog

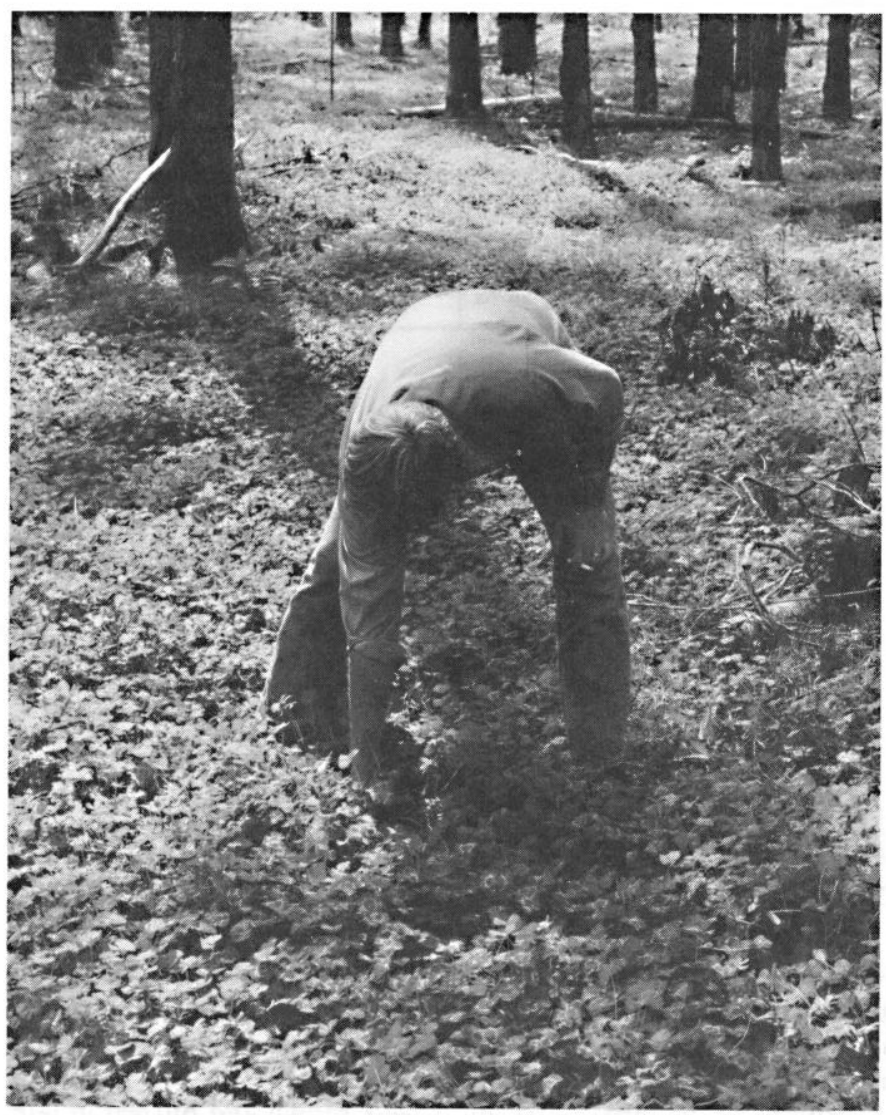

Fig. 3. Subclover growing under pine timber thinned for sawlog production.

production. The reduction in yield compared to cleared land is statistically significant, but is probably not economically significant considering potential land clearing costs and the loss of timber revenue. Furthermore, pine timber often responds to fertilization, so increased timber revenue may off-set opportunity costs of deferring higher animal production. These aspects of producing subterranean clover under pine forests require further study.

\section{Literature Cited}

Association of Official Analytical Chemists. 1970. Official methods of analysis. 11th ed. Ass. Off. Anal. Chem. Washington, D.C.

Blair, R.M., H.L. Short, and E.A. Epps, Jr. 1977. Seasonal nutrient yield and digestibility of deer forage from a young pine plantation. J. Wildl. Manage. 41:667-676.

Date, R.A. 1970. Microbiological problems in the inoculation and nodulation of legumes. Plant and Soil 32:703-725.

Davis, L.G. 1983. Production of subterranean clover in Louisiana pine forests. M.S. Thesis, Louisiana State Univ., Baton Rouge.

Gardner, E.H., T.L. Jackson, W. Mosher, L. Cannon, W.S. McGuire, and T.E. Bedell. 1979. Subclover-grass pastures in western Oregon. Oregon State Univ. Fert. Guide 4.

Halls, L.K., and R.F. Suman. 1954. Improved forage under southern pines. J. Forest. 52:848-851.

Jones, M.B., P.W. Lawler, and A.H. Murphy. 1971. Establishment of subclover in relation to nodulation, time of seeding, and climatic variations. J. Range Manage. 24:147-150.

Knight, W.E., H.D. Palmertree, and V.H. Watson. 1976. Growing subterranean clover in Mississippi. Mississippi Agr. Forest Exp. Sta. Inf. Sheet 1268.

Lay, D.W. 1957. Some nutritional problems of deer in the Southeast pine type. Proc. Southeast Ass. Game and Fish Comm. Conf. 10:53-58.

McLaughlin, S.P. 1978. Overstory attributes, light, throughfall, and interpretation of overstory-understory relationships. Forest. Sci. 24:550-553.

Morley, F.H.W. 1961. Subterranean clover. Adv. Agron. 13:57-123.

Ozoga, J.J., and L.J. Verme. 1982. Physical and reproductive characteristics of a supplementary fed white-tailed deer herd. J. Wildl. Manage. 46:281-301. 
Peevy, W.J. 1972. Soil test results and their use in making fertilizer and lime recommendations. Louisiana State Univ. Agr. Exp. Sta. Bull. 660, Univ. Station, Baton Rouge.

Shinet, T.N. 1980. What is the resource? p. 17-28. In: R.D. Child and E.K. Byington, (Eds.) Proc. South. Forest Range and Pasture Resour. Winrock Internat. Livestock Res. and Training Center. Petit Jean, Mnt., Morrilton, Ark.

Snedecor, G.W., and W.G. Cochran. 1973. Statistical methods. 4th Edition. lowa State Univ. Press, Ames.
Steel, F.G.D., and J.H. Torrie. 1980. Principles and procedures of statistics. McGraw-Hill Book Co., New York.

Strickler, G.S. 1959. Use of the densiometer to estimate density of forest canopy on permanent sample plots. USDA Forest Serv. Res. Note. NW-180.

Toms, J. 1958. Seeding depth of Dwalganup subterranean clover. J. Dep. Agr. W. Aust. 7:555-557.

Wolters, G.L. 1981. Timber thinning and prescribed burning as methods to increase herbage in grazed and protected longeleaf pine range. J. Range Manage. 34:494-497. 